\title{
Retrospective comparison of iloprost with other treatments for secondary Raynaud's phenomenon
}

Cardiovascular
Research Unit,

Schering Health Care

Limited, The Brow,

Burgess Hill,

West Sussex RH15 9NE

H R Watson

G Belcher

Correspondence to:

Dr Watson.

Accepted for publication

22 June 1990

\begin{abstract}
One hundred and twenty seven patients who had Raynaud's attacks secondary to connective tissue disease received intravenous infusions of iloprost in controlled clinical trials. Results of previous treatments for Raynaud's attacks had been recorded by clinicians in 84 of these cases, allowing a comparison to be made with the response to iloprost treatment. Iloprost was reported by the patients as beneficial in $49(58 \%)$ of 84 cases, whereas only $36(43 \%)$ of the 84 patients had previously found any other treatment to be useful. Twenty four of $48(50 \%)$ patients who had not responded to any previous treatment found iloprost to be of benefit. Success or failure of treatment with iloprost was not accurately predicted by the result of treatment with any other drug, except prostacyclin. This survey suggests that iloprost is a useful treatment for patients with severe secondary Raynaud's phenomenon and can be effective in patients unresponsive to other treatments.
\end{abstract}

For patients with secondary Raynaud's phenomenon, who are usually not adequately treated by any single method, it is not easy to determine the place of a new treatment among the many already available. Conventionally, treatments are compared in prospective controlled clinical trials, but multiple comparisons in parallel group design trials require larger numbers of patients than are available with such a rare condition. Trial designs in which treatments are taken sequentially are not ideal either, owing to seasonal variation and the progressive nature of the disease. Sequential use of different treatments in the same patient is, however, the only way to determine whether non-responders to one drug will benefit from a different one, or whether a lack of response to one agent is predictive of a lack of response to another.

Iloprost is a chemically stable analogue of prostacyclin, which has been investigated as a treatment for Raynaud's phenomenon secondary to connective tissue diseases. The drug has been shown to be more effective than placebo, ${ }^{12}$ and comparable with nifedipine in a parallel group design trial. ${ }^{3}$ It remains to be established whether or not the patients responding to iloprost are the same patients who are currently satisfactorily treated by nifedipine. Information on the efficacy of iloprost in patients who have previously failed to respond to the many other drugs used for treatment of Raynaud's phenomenon is also required.
These requirements suggest that a retrospective within-patient comparison of the results of different treatments may be appropriate. ${ }^{45}$ The accumulated data from clinical trials of iloprost in secondary Raynaud's phenomenon were used to compare the benefit from iloprost with that obtained from previous treatments.

\section{Patients and methods}

One hundred and twenty seven patients, who had been entered into six clinical trials of iloprost for secondary Raynaud's phenomenon, ${ }^{1} 36{ }^{3}$ were considered for inclusion in the survey. They were drawn from eight hospitals in the United Kingdom and the Netherlands, and each had been diagnosed as having Raynaud's attacks secondary to connective tissue disease. In 110 cases $(87 \%)$ the underlying condition was systemic sclerosis as defined by the American Rheumatism Association. ${ }^{8}$

In each trial the clinicians were asked to record previous treatments that the patients had received for their Raynaud's attacks and the outcome. Patients were considered to have benefited from a previous treatment even if the improvement was described as mild or slight, but they were not considered to have benefited if the treatment had to be discontinued owing to side effects.

Patients were each asked at the end of a six to 10 week follow up after iloprost treatment whether they considered that their Raynaud's attacks had improved after that treatment. The iloprost treatment consisted of six to eight hour intravenous infusions given on three consecutive days at an infusion rate of up to 2.0 $\mathrm{ng} / \mathrm{kg} / \mathrm{min}$. A comparison was made of patients' response to iloprost and to previous treatments.

Thirty five patients who were given placebo infusions on three consecutive days were assessed in the same manner as those receiving iloprost. Responses to placebo and previous treatments were compared to give an overall view of the efficacy of iloprost and placebo compared with other treatments.

\section{Results}

Information on the outcome of both iloprost and other treatments was available for 84 of the 127 patients. For the other patients either no previous treatments were recorded or the outcome of these treatments was not known. Thus the study group comprised 84 patients. In total, the 84 patients had received 165 treatments for Raynaud's phenomenon before inclusion in the iloprost trials. The average number of different 
Table 1 Comparison of the number (\%) of patients benefiting from iloprost or placebo with the number benefiting from any previous treatments

\begin{tabular}{|c|c|c|c|c|c|}
\hline \multirow{2}{*}{$\begin{array}{l}\text { Trial } \\
\text { drug }\end{array}$} & \multirow{2}{*}{$\begin{array}{l}\text { Number of } \\
\text { patients receiving } \\
\text { trial drug }\end{array}$} & \multicolumn{4}{|c|}{ Number of patients obtaining benefit from: } \\
\hline & & $\begin{array}{l}\text { Trial drug } \\
\text { alone }\end{array}$ & $\begin{array}{l}\text { Both trial drug and } \\
\text { previous treatment }\end{array}$ & $\begin{array}{l}\text { Previous } \\
\text { treatment alone }\end{array}$ & $\begin{array}{l}\text { Neither trial drug } \\
\text { nor previous treatment }\end{array}$ \\
\hline $\begin{array}{l}\text { Iloprost } \\
\text { Placebo }\end{array}$ & $\begin{array}{l}84 \\
35\end{array}$ & $\begin{array}{c}24(28 \cdot 5) \\
1(3)\end{array}$ & $\begin{array}{l}25(30) \\
10(29)\end{array}$ & $\begin{array}{l}11(13) \\
15(43)\end{array}$ & $\begin{array}{c}24(28 \cdot 5) \\
9(26)\end{array}$ \\
\hline
\end{tabular}

Table 2 Comparison of the number of patients benefiting from iloprost with the number benefiting from individual previous treatments

\begin{tabular}{|c|c|c|c|c|c|}
\hline \multirow{2}{*}{$\begin{array}{l}\text { Previous } \\
\text { treatment }\end{array}$} & \multirow{2}{*}{$\begin{array}{l}\text { Number of } \\
\text { patients receiving } \\
\text { treatment }\end{array}$} & \multicolumn{4}{|c|}{ Number of patients obtaining benefit from: } \\
\hline & & $\begin{array}{l}\text { Iloprost } \\
\text { alone }\end{array}$ & $\begin{array}{l}\text { Both iloprost and } \\
\text { previous treatment }\end{array}$ & $\begin{array}{l}\text { Previous } \\
\text { treatment alone }\end{array}$ & $\begin{array}{l}\text { Neither iloprost } \\
\text { nor previous treatment }\end{array}$ \\
\hline $\begin{array}{l}\text { Nifedipine } \\
\text { Prostacyclin } \\
\text { Gamolenic acid } \\
\text { Inositol nicotinate } \\
\text { Naftidrofuryl } \\
\text { Ketanserin } \\
\text { Prostaglandin E } \\
\text { \& Blockers } \\
\text { Sympathectomy }\end{array}$ & $\begin{array}{r}56 \\
13 \\
12 \\
11 \\
10 \\
9 \\
8 \\
8 \\
14\end{array}$ & $\begin{array}{r}18 \\
0 \\
4 \\
3 \\
5 \\
2 \\
3 \\
1 \\
4\end{array}$ & $\begin{array}{r}12 \\
8 \\
5 \\
2 \\
1 \\
0 \\
3 \\
1 \\
5\end{array}$ & $\begin{array}{l}6 \\
2 \\
1 \\
1 \\
0 \\
0 \\
1 \\
2 \\
1\end{array}$ & $\begin{array}{r}20 \\
3 \\
2 \\
5 \\
4 \\
7 \\
1 \\
4 \\
4\end{array}$ \\
\hline
\end{tabular}

previous treatments given to these patients was two (range one to eight). Thus many patients had proved unresponsive to a number of different treatments.

Forty nine (58\%) of the 84 patients benefited from the iloprost treatment. Of 48 patients $(57 \%)$ who had not benefited from any treatment before entering the trial (table 1), 24 were found to have benefited from iloprost infusions. Conversely, of the 36 patients who had derived some benefit from previous treatments, only 11 (31\%) did not respond to iloprost. Of 35 patients receiving placebo infusions in the same trials, $11(31 \%)$ showed some benefit from these infusions. But of the $10(28 \%)$ who had not responded to any previous treatment only one patient found placebo beneficial (table 1).

The most commonly used drug was nifedipine, given to 56 patients (table 2). Results with iloprost and nifedipine were the same in only $32(57 \%)$ cases. Of the 38 patients who had not benefited from nifedipine, $18(47 \%)$ were helped by iloprost. Ten of these 38 patients $(26 \%)$ had had nifedipine withdrawn owing to side effects. Of the 18 patients who had benefited from nifedipine, 12 (67\%) also responded to iloprost.

Comparison of the response to prostacyclin and iloprost showed a close correlation, but the comparison with other more commonly used treatments (gamolenic acid, inositol nicotinate, naftidrofuryl, ketanserin, prostaglandin $E_{1}, \alpha$ blockers, and sympathectomy) showed in each case that a proportion of the patients responded to iloprost even though previous treatments had failed to produce any relief of symptoms (table 2). Unlike nifedipine, none of these drugs was withdrawn because of intolerable side effects.

\section{Discussion}

The results show that iloprost was considered to be helpful by half of the patients who had not found any previous treatment to be beneficial and by most patients who had benefited from previous treatments. The same picture emerged from a comparison with individual drugs or sympathectomy. Success or failure of treatment with any of the previously tried drugs was not predictive of success or failure with iloprost, except in the case of prostacyclin. This last result might be expected as iloprost is a prostacyclin analogue.

Hitherto, the most effective drug for the treatment of Raynaud's phenomenon has generally been considered to be nifedipine. ${ }^{9}$ Of patients included in these trials, however, 38/56 had found nifedipine ineffective. Of these 38, $18(47 \%)$ benefited from iloprost treatment. This finding supports the view of Rademaker $e t$ $a l$ that iloprost and nifedipine are both effective in secondary Raynaud's phenomenon but by different mechanisms and not necessarily, therefore, helping the same patients. ${ }^{3}$

Use of retrospective group comparisons has been criticised. ${ }^{10} \mathrm{~A}$ within-patient retrospective comparison such as this may be acceptable, however. In all such studies the accuracy and completeness of the information available is open to question. For example, the number of treatments previously tried in these patients is likely to have been underrecorded, but this would tend to underestimate the severity of the patients' condition.

Placebo infusions were clearly shown to be less helpful than previous treatments, indicating that the favourable comparison of iloprost with previous treatments cannot be attributed to the effects of admitting patients to hospital for intravenous treatment, nor to the methods used in this retrospective study. These data do not represent a comparison of efficacy of the treatments in all patients with Raynaud's phenomenon, however, as there is a patient selection bias in favour of those who had failed to respond adequately to other drugs. It is these who are entered into trials of new therapeutic agents. Furthermore, details of the regimen for previous treatments were not recorded, whereas the 
iloprost regimen was carefully monitored. Nonetheless, most patients in this survey had failed to benefit from any previous treatment and the finding that iloprost was beneficial in half of these patients is useful in assessing the value of the drug in clinical practice.

Assessment of patient response as an all or nothing event is not entirely satisfactory, but to have attempted a more subtle description of response would have been to risk overinterpretation of the data available. The lack of objective measurements of response is unavoidable as there is no test which consistently correlates improvement with relief of symptoms in Raynaud's phenomenon.

A final source of bias in this survey is the progressive nature of the condition. Any bias from this source would, however, be expected to favour the earlier treatments, thus reinforcing the conclusion that iloprost is a useful drug for the treatment of Raynaud's phenomenon secondary to connective tissue disease which may offer some relief of symptoms to patients not previously helped by any other treatment.
We thank Professor P J Maddison for valuable discussion and advice.

1 McHugh N J, Csuka M, Watson $\mathrm{H}$, et al. Infusion of iloprost, a prostacyclin analogue, for treatment of Raynaud's 47: 43-7.

2 Yardumian D A, Isenberg D A, Rustin M, et al. Successful treatment of Raynaud's syndrome with iloprost, a chemically stable prostacyclin analogue. $B r \mathcal{F}$ hewomatol 1988; 27: stable 220 .

3 Rademaker M, Cooke E D, Almond N E, et al. Comparison of intravenous infusions of iloprost and oral nifedipine in treatment of Raynaud's phenomenon in patients with systemic sclerosis: a double-blind randomised study. $B M \mathcal{F}$ 1989; 298: 561-4.

4 Blackburn H. Commentary: observation versus experiment. Stat Med 1984; 3: 401-3.

5 Cranberg $L$. Do retrospective controls make clinical trials "inherently fallacious?" BMY 1979; ii: $1265-6$.

6 Torley H I, Madhok R, Capell H A, et al. Low dose iloprost in secondary Raynaud's. Br $\mathcal{Y}$ R hewematol 1988; 27 (suppl 2): 110.

7 Rademaker M, Thomas R:H M, Provost G, Beacham J A Cooke E D, Kirby J D. Prolonged increase in digital blood flow following iloprost infusion in patients with systemic sclerosis. Postgrad Med $\mathcal{Y}$ 1987; 63: 617-20.

8 Masi A T, Rodnan G P, Medsger T A, et al. Preliminary criteria for the classification of systemic sclerosis (scleroderma). Anhritis Rhewon 1980; 23: 581-90.

9 Dowd P M. The treatment of Raynaud's phenomenon. $\mathrm{Br} \mathcal{J}$ Dermatol 1986; 114: 527-33.

10 Pocock S J. Clinical trials: a practical approach. Chichester: 